\title{
YUGOSLAV REFUGEES, DISPLACED PERSONS AND THE CIVIL WAR
}

\author{
Mirjana Morokvasic \\ Freie Universität, Berlin and \\ Centre Nationale de la Recherche Scientifique, Paris
}

\section{Background}

Slovenia and Croatia declared independence on 25 June 1991. That was the date of the "collective thanatos"1. which led to the disintegration of Yugoslavia. As a result of German pressure, the European Community, followed by a number of other states, recognized the independence of the secessionist republics on 15 January 1992 and buried the second Yugoslavia. ${ }^{2}$

Although the Western media have now shifted their attention to the former Soviet Union, where other similar and potentially even more dangerous ethnic conflicts are brewing, that is not because genuine peace has been established in former Yugoslavia. To the contrary: blood continues to flow among the civilian population and among military and paramilitary personnel. As I write, the war is spreading to Bosnia and Herzegovina and threatens to turn into a disaster of far wider scope than the war in Croatia. The conflict has already claimed 3,083 civilian victims according to Croatian sources. The Yugoslav Army has confirmed about 1,279 dead soldiers. But it is reliably estimated that from 10,000 to 30,000 people have been killed in all and another 30,000 people are reported missing. ${ }^{3}$

The estimated number of refugees ranges from 600,000 to over 1 million. ${ }^{4}$ This is the third mass migration of Yugoslavians since 1939. The first consisted of people fleeing persecution in the Second World War and the mainly involuntary internal migration and emigration of Yugoslavians in the immediate post-war period. The second mass population movement was a legal labour migration, mainly to various West European countries as part of the "guest worker" programme of the 1960 s and 1970 s. It was a unique case among the socialist countries. The present tragedy can only be compared to that of the Second World War; from an international perspective, the United Nations High Commission on Refugees (UNHCR) compares it in scope, scale of atrocities and consequences for the population, to the Cambodian civil war.

In three ways, analyzing the refugees' situation contributes to our understanding of issues beyond the human tragedy of the people themselves. First, it demystifies the genesis of the Yugoslav conflict, which is often reduced to a matter "ethnic hatred." It shows that the separation of populations along ethnic lines, while favoured by the power elites of Croatia, Slovenia and Bosnia-Herzegovina, only intensifies existing problems or creates new ones. Second, it draws attention to a category of refugee for whom "political refugee" status does not apply and therefore underscores the need to grant these people more security and protection than they have so far enjoyed. Third, given the relatively small number of refugees who have fled abroad compared to the number who have sought refuge within the boundaries of former Yugoslavia, the Yugoslav case may also help de-dramatize the East/West invasion scenarios which predict disruptive mass movements caused by political and ethnic violence or ecological catastrophe in the countries aligned with the former Soviet empire. The Demographic Structure

The 600,000 to 1 million displaced persons referred to above come from Croatia, whose total population is 4.7 million (see Figure 1). Moreover, most of these people come from a relatively small area - the front line, which is now under the control of the Yugoslav Army and Serbian forces. This means that in the course of six months, an average of at least 100,000 people were forced to leave their homes each month. Vast areas have been devastated and depopulated.

In general, the destinations of the refugees are the larger urban centres notably the capitals of the republics, but also such regions as Vojvodina and Istria. About 300,000 refugees have sought shelter in safe areas of Croatia. Over 160,000 have fled to Serbia (including Vojvodina), around 100,000

Table 1: Number of Displaced Persons by Region of Destination, Yugoslavia, 31 December 1991 and 10 February 1992

$\begin{array}{lccc} & 31 \mathrm{Dec} / \mathbf{9 1} & \text { 10 Feb/92 } & \text { Percent Change } \\ \text { Croatia } & 311,000 & 321,966 & 3.5 \\ \text { Serbia proper } & 90,414 & 99,993 & 10.6 \\ \quad \text { Vojvodina } & 59,822 & 61,390 & 2.6 \\ \quad \text { Kosovo } & 1,169 & 1,519 & 29.9 \\ \text { Bosnia-Herzegovina } & 100,000 & 92,094 & -7.9 \\ \text { Slovenia } & 23,000 & 16,000 & -30.4 \\ \text { Montenegro } & 7,000 & 7,450 & 6.4 \\ \text { Macedonia } & 2,050 & 2,400 & 17.1 \\ \text { Total } & \mathbf{5 9 4 , 4 5 5} & \mathbf{6 0 4 , 8 1 2} & 1.7\end{array}$

Source: International Red Cross 
to Bosnia and Herzegovina and 23,000 to Slovenia. As Table 1 suggests, the most recent events - increasing tensions and hostilities over the future of the multiethnic republic of Bosnia and Herzegovina - have now established a reverse trend: refugees have been leaving Bosnia and Herzegovina at a rate of several thousand a day. In only one day, 29 March 1992, 6,000 refugees crossed the bridge connecting the Bosnian town of Bosanski Brod with the Croatian town of Slavonski Brod, transforming the latter, with its 55,000 inhabitants, into a large refugee camp. ${ }^{5}$

Far fewer people have sought shelter abroad than in Yugoslavia itself. ${ }^{6}$ That is because people know their chances of receiving political asylum are practically nil. In Germany, for example, only about one percent of Yugoslavian asylum seekers in 1991 actually received asylum. In the fall of 1991 most of the Yugoslavs who entered various European countries as tourists remained underground until the decision adopted by most of the

Fig. 1: Refuge日 Movements in Yugoslavia

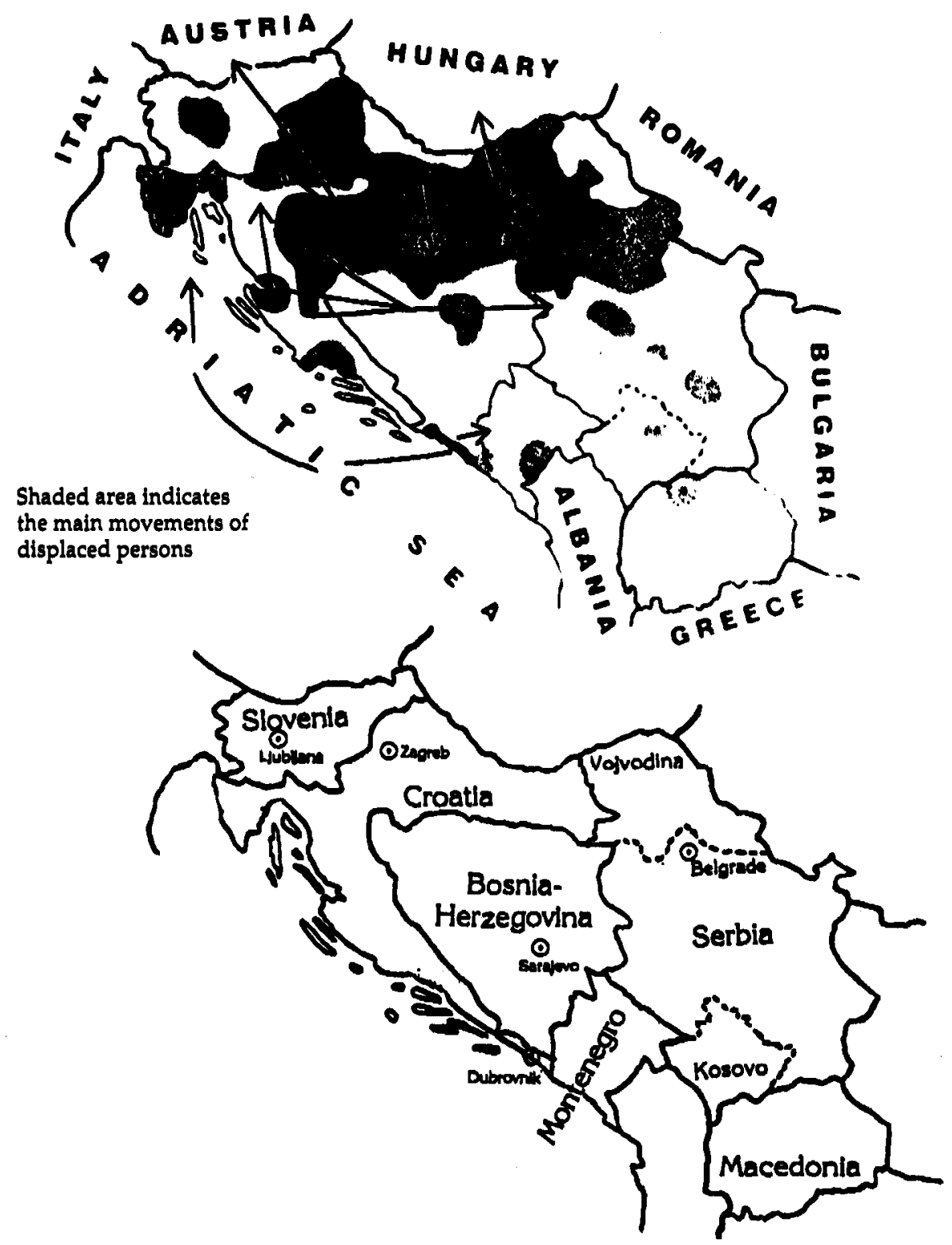

countries to 'tolerate' their presence for the time being was made public. The recent Swiss decision to repatriate 14,000 Yugoslavs "because their lives were no longer in danger," has been criticized by the UNHCR in Geneva. In Germany, the target country of most Yugoslav asylum-seekers and refugees not requesting asylum (estimates of the number of such people vary from 50,000 to 150,000 ), the decision not to repatriate them was taken at a conference of Ministers of the Interior of the Länder on 8 November 1991. The decision applies to refugees from Croatia and to deserters from the Yugoslav army. Refugees are granted financial aid whether they apply for asylum or not.?

The main receiving countries are neighbouring Hungary and the countries where Yugoslavs previously went as migrant labourers. One may reasonably assume that newly arriving refugees in the latter countries are greeted by already-established friendship and kin networks. In France, visa requirements were imposed in 1986 for Yugoslavs and that has deterred the inflow of refugees. Elsewhere in Western Europe, Yugoslavs, together with Romanians, rank first in number of asylum applicants.

Among migrants within former Yugoslavia, women and children under fifteen years of age represent two-thirds of the refugee flow: ${ }^{8}$ (Men were either drafted into the military or are hiding and therefore do not appear in the official figures.) For an entire generation of former Yugoslavia's youth, this has had disastrous effects on their critically important period of childhood development.

The war zone from which the refugees come was an ethnically mixed area for centuries (see Figure 1). Villages tend to be predominantly Serb or Croat, depending on the region. But in urban areas, Croats, Serbs, Ukrainians, Czechs, Slovaks and Hungarians lived as neighbours and intermarried. Thus, before the war, Vukovar had 40,000 inhabitants, 43 percent of whom were Croats, 37 
percent Serbs, 7.3 percent Yugoslavs, 1.6 percent Hungarians and 3.5 percent other ethnic origins. 9

In front-line towns such as Vukovar, Daruvar, Pakrac, Beli Manastir, Osijek and Petrinja, the proportion of "Yugoslavs" (people who refused to define themselves as Serbs, Croats, etc.) was increasing constantly until the 1981 census, when it was around 20 percent. The proportion of Yugoslavs fell to 15 percent in 1991 due to nationalist propaganda and subsequent ethnic polarization. The war and the ensuing displacement of persons created further polarization and ethnic homogenization: Croats fled mainly to Croatia, Serbs to Serbia and to BosniaHerzegovina. Clearly, people who spoke one language, shared the same culture and intermarried could only be separated by such violent methods.

Assuming that most of those who found shelter in Serbia, and at least half of those who found shelter in BosniaHerzegovnia, are Serbs, one arrives at a total of 200,000 to 250,000 Serbian internal refugees. Knowing that the number of Serbs in Croatia was around 600,000 according to the 1991 census, this means that one-third of the total Serbian population of Croatia is in exile. This underestimates the actual number, however, because it takes into account only the official UNHCR figures. One would also have to include deserters from the military and paramilitary forces, refugees abroad and missing persons in order to arrive at a total figure. In any case, these huge numbers highlight the grotesqueness of the Yugoslav army and Serbian government assertion that "the Federal Army's intervention was meant to 'protect' the civilian population of Croatia." In reality, the military intervention served only the purposes of Tudjman and Milosevic: it separated ethnic populations, especially where they were geographically and socially mixed and "purified" the newlycreated ethnic states.

Since people did not live in isolated, ethnically pure enclaves, the situation has been a disaster, in particular in binational families - and in some front-line towns fully half of all families were ethnically mixed. Among the many families who resisted separation along ethnic lines, the war produced thousands of stateless persons, with no place to go and no place to go back to. Wherever they reside, Serbia or Croatia, such people are now considered potential enemies, "traitors against the nation." One person from a mixed marriage whom I interviewed reported that:

I have always been closer to my mother.

I felt Croatian, Catholic, I even went to church. But I have now repeatedly been told that I cannot stay in Croatia and keep my job - not even with a singledrop of Serbian blood in my veins. The situation became unbearable, so I left for Belgrade where I thought I would be better accepted; but there I was an 'Ustascha Croat.'

This person eventually applied for asylum in Germany.

The fate of such refugees demonstrates the fallacy of ethnic solutions to the Yugoslavian problem. There are about three million Yugoslavs - one eighth of the whole population - who are unable to accept ethnic citizenship in place of their Yugoslav citizenship, either because they come from mixed marriages or because they have lived in different parts of Yugoslavia and have established close ties with people throughout the country. ${ }^{10}$ No solution is foreseen for these "leftover Yugoslavs," no one represents them in peace talks, there is no one to guarantee their human rights, which are constantly violated or under threat. Their situation brings to mind Hannah Arendt's statement that "one glance at the demographic map of Europe should be sufficient to show that the nation-state principle cannot be introduced into Eastern Europe." ${ }^{11}$ In Yugoslavia, multi-ethnicity was a way of life. As one of the first expressions of their sovereignty, the nation-states that have emerged in its place have denaturalized people, stripping them of their citizenship: people born in Slovenia and Croatia have to apply and provide proof of their blood origin.
Amidst all the nationalistic euphoria, non-nationalist expressions took much longer to get articulated. It was only in February 1992 that the Civil Resistance Movement was created by people from various parts of former Yugoslavia to protect the rights of people who come from ethnically mixed families and identify themselves as Yugoslavs.

\section{Motives for Fllght}

Outbursts of hatred and violence did not cause the war, as has usually been assumed. Rather, hatred and violence are the war's by-products. The war revived memories of Second World War massacres. But that was after almost half a century of peaceful coexistence and the widespread disregard of nationality and religion. The use of Goebelsian propaganda in a steady, aggressive media war was necessary to disrupt that situation.

Several surveys drive home the point. The most recent one was conducted in Serbia among 650 refugees from Croatia, who originated in 52 ethnically heterogeneous communities. Two-thirds of the respondents came from minority groups in their communities. Some 86 percent of them had ethnic origins that differed from those of their neighbours, while 96 percent had established friendships and 66 percent had family relations with members of other ethnic groups. Fully 60 percent denied the existence of national divisions or of national intolerance in their communities and 77 percent had not had personal conflicts with members of other ethnic groups. Only 5.5 percent gave evidence of a continuous atmosphere of ethnic division and intolerance. Only 1.2 percent were able to give evidence of personal conflicts with members of other ethnic groups and a mere 0.8 percent were able to give evidence of collective forms of such conflict. The situation described by these data started changing during the first free multiparty election campaign in Croatia in 1991. Relations with friends, neighbours and even family relations deteriorated.

When asked about the reasons for their flight, most respondents replied 
"fear." People who left their homes as early as the spring of 1991 more frequently mentioned direct attacks and ill treatment in general than those who left later. People who fled later expressed a more general fear for life as the war spread and indiscriminate artillery attacks escalated in frequency. ${ }^{12}$

\section{Roturn?}

Most of the refugees who took part in the survey -61.3 percent - expressed the desire to return home. Only 9.4 percent said they would not return and 29.5 percent did not know. The greatest readiness to go home was shown by peasants, who also had the fewest escape options and were the first victims of criminal attacks and massacres by troops.

The UNHCR is presently preparing a detailed plan for the repatriation of refugees to areas which will be under the control of the UN protection forces (UNPROFOR) and which are now occupied by the Federal Army and Serbian Forces. It is assumed that the returning population will be the same as the population that fled. However, in many cases refugees either do not have anywhere to return to because their houses have been destroyed or they still do not know what shape their houses are in. Many have lost their families and need support to find new meaning in life. In addition, most refugees still fear for their safety if they return. The official and unofficial messages from their regions are crystal clear: refugees can expect to be arbitrarily branded as traitors or war criminals, to be victims of revenge by the extremist gangs and paramilitary formations which nobody has so far been eager to take to court for war crimes. It is therefore unlikely that the protection of basic human rights would be better guaranteed in the regions under UNPROFRO supervision. This situation prevents easy repatriation.

On the other hand, refugees are also under increasing pressure in the places where they have found temporary shelter. Over 80 percent of all refugees are being taken care of by friends and relatives. The rest are in collective shelters. A $\$ 24$ million aid package provided by UNHCR, UNICEF and the World Health Organization (WHO) targets 500,000 Yugoslavs displaced in their own country by war and covers primarily food parcels, medical help, drugs and logistics. ${ }^{13}$ Nonetheless, receiving families are decreasingly able to shoulder the rest of the burden, in particular in poorer parts of the country such as Bosnia and Herzegovina. ${ }^{14}$ The new Serbian law on refugees contributes to their insecurity: according to its article 18 , refugees can be stripped of their status and sent back "when the situation changes." This means that the Serbian government, which conducted an undeclared war in order to "protect the Serbian population outside Serbian borders," could decide to repatriate Serbs in the same way as Switzerland, claiming that there is no longer any danger to life in their areas of origin. ${ }^{15}$

\section{Deserters}

In October 1991, M. Milenkovic, a Yugoslav soldier from Serbia, committed suicide. He could not choose between becoming a "traitor" by abandoning the front line and killing his compatriots. ${ }^{16}$ In Serbia he became the symbol of the growing resistance to the war among potential draftees and civilians in general.

Strong anti-war feelings were widespread even before the beginning of hostilities. According to one survey conducted 25-29 July 1991, only a small minority of people in most major cities claimed that war was "the best means of preserving state or national honour." Only 1 percent of respondents in Ljubljana, 4 percent in Belgrade and 10 percent in Zagreb thought that people should volunteer for the army if the local governments decided to start a war.

By the end of 1991 it was estimated that around 100,000 young men had fled to Western Europe in order to avoid being drafted by the Croatian National Guard and that about 150,000 escaped mobilization by the Yugoslav
Federal Army by crossing the borders. In Serbia some 10,000 cases of desertion or of failure to respond to mobilization are being prosecuted. ${ }^{17}$ In most cases, resistance to the war among recruits has been passive and silent, but there have also been cases involving the mass desertion of several hundreds or thousands of recruits, of public demonstrations and of spectacular acts like that of a soldier who drove his armoured car from the Slavonian front to the centre of Belgrade and parked it in protestin front of theSerbian Parliament. Although in principle deserters risk the death penalty, so far only a few soldiers have been punished by the military. ${ }^{18}$

As early as August 1991 pacifists in Belgrade publicly called for men to refuse mobilization and for soldiers to desert. Their statements ran counter to official war propaganda and to traditional warrior attitudes which are even now represented in public opinion and among parliamentarians: there were even proposals in the Serbian parliament for a bill that would forbid return to all those who left the country because of the war. This proposal did not win the necessary majority and was defeated. However, parliament also rejected the counterproposal: an amnesty bill that would guarantee safe return and no sanctions against deserters. ${ }^{19}$

\section{Conclusion}

The "return of nations" in Eastern and Central Europe, the creation of new ethnically homogeneous nation-states, demands a very high price for its realization. Can the Yugoslav tragedy serve as a sufficient warning to others? Nationalism, the credo of the power elites in former Yugoslavia - the "supreme stage of communism" as Adam Michnik mockingly called it - has transformed into victims precisely those in whose name and for whose "benefit" the war has allegedly been fought: the civilian population. Thousands have died, thousands more have become invalids, hundreds of thousands are refugees in what used to be their own country. That is the tragic legacy of the latest war in the Balkans. 圆

(Footnotes on page 8) 